\title{
CONCEPTUAL SKILLS IN PERSONS WITH VISUAL IMPAIRMENT'
}

\author{
Marija ANĐELKOVIĆ2 \\ University of Belgrade \\ Faculty of Special Education and Rehabilitation
}

Conceptual skills enable the development of abilities necessary for controlling certain aspects of life. They include communication skills, functional literacy, and self-direction skills. The aim of this paper was to determine the acquisition of conceptual skills in persons with visual impairment. The research was conducted on a sample of 127 persons with visual impairment, 19-60 years of age. Conceptual Skills Domain of Adaptive Behavior Assessment System II (ABASII) was used to obtain data on the acquisition of conceptual skills. It was determined that age $(p=0.001)$ and the category of visual impairment (blindness and low vision) $(p=0.000)$ were significant factors for the acquisition of conceptual skills in persons with visual impairment. On the other hand, time when vision loss occurred was not a significant factor for acquiring conceptual skills in persons with visual impairment $(p=0.195)$.

Keywords: visual impairment, conceptual skills, communication skills, functional literacy, self-direction skills

1 This paper is the result of the research project "Creating a protocol for assessing educational potentials of children with disabilities, as a criterion for the development of individual educational programs", ON 179025 (2011-2015), financed by the Ministry of Education, Science and Technological Development of the Republic of Serbia

2 E-mail: marijaandja14@yahoo.com 
Specijalna edukacija i rehabilitacija (Beograd), Vol. 16, br. 1. 9-33, 2017.

\section{INTRODUCTION}

Conceptual skills are the basis for acquiring the ability to control certain aspects of life, such as understanding abstract ideas, problem solving, understanding relations and the ways in which organized systems function. Conceptual skills include communication skills, functional literacy, and self-direction skills within the concept of adaptive behavior.

Communication skills include receptive and expressive language, and non-verbal communication. Abilities to read, write and apply basic mathematical operations in everyday life are integral parts of functional literacy. Self-direction skills include independent and responsible behavior, selfcontrol, beginning tasks, following instructions, schedules and deadlines, completing tasks, making decisions and making personal choices. Some self-direction skills are acquired while growing up, while others depend on the cultural context.

According to the results of previous studies adaptive skills are in moderately low range in children and youth with visual impairment compared to the norm sample (Papadopoulos, Metsiou \& Agaliotis, 2011). Conceptual skills are more acquired than practical skills, but not more than social skills (Papadopoulos, Metsiou \& Agaliotis, 2011). In the mentioned research, the participants had the lowest achievements on the Written subtest, which assessed success in reading school books, newspaper articles, and other texts. Children and youth with visual impairment had the best achievements on Receptive subtest, and somewhat worse on Expressive subtest. Their achievements on Problem Solving subtest which belonged to social domain within this scale were somewhat better compared to achievements on subtests which belonged to conceptual skills domain. On the other hand, older participants achieved better results in communication skills domain. However, when compared to the norm group, developmental delay was also present. Gender and variables related to vision (visual acuity, visual field, time of vision loss) 
were not significant factors for acquiring communication skills and skills needed to solve a problem.

Children with visual impairment do not have major difficulties in acquiring conceptual skills which primarily refers to structural aspect of a language (phonetics, phonology, grammar, and semantics). This is due to the fact that there were no significant differences in their achievements compared to typically developing children (James \& Stojanovik, 2007), which was also determined in the above mentioned study conducted by Papadopoulos et al. Most authors agree that visual impairment has a negative influence on pragmatic and social aspects of language structure (James \& Stojanovik, 2007; Tadić, Pring \& Dale, 2010). When considering language development of children with visual impairment, there are examples which point to deficits in certain segments of pragmatic skills, such as: difficulties in initiating and maintaining communication, absence of communication gestures, and lack of interest in conversation (Frame, 2000; James \& Stojanovik, 2007; Perfect, 2001; Tadić et al., 2010; Yildiz \& Duy, 2013). Inability to follow visual signals limits interpersonal communication in blind persons (Jindal-Snape, 2005; Kim, 2003; Mallineni, Nutheti, S. Thangadurai \& P. Thangadurai, 2006). Blind people usually don't understand the significance of facial expression in communication, and are not aware of reactions certain facial expressions can provoke in interlocutors (Cole, 1998, according to Galati, Sini, Schmidt \& Tinti, 2003; Vučinić, Jablan, Stanimirović \& Drinčić, 2015).

Reading in persons with visual impairment to a great extent depends on the condition of visual functions (visual acuity, contrast sensitivity, and visual field) (Tabrett \& Latham, 2012). This primarily refers to speed. Studies have shown that low vision and blind children read more slowly than their typically developing peers (Dodd \& Conn, 2000; Douglas, Hill, Long \& Tobin, 2001; van Bon, Adriaansen, Gompel \& Kouwenberg, 2000), however, no difference in reading fluency was determined between them (Bosman, Gompel, Vervloed \& van Bon, 2006; de Verdier \& Ek, 2014; Gompel, 
van Bon, Adriaansen \& Schreuder, 2002; Gompel, van Bon \& Schreuder, 2004; Mohammed \& Omar, 2011). People with visual impairment do not have major difficulties in reading if the text is adapted to their needs (Braille or large print). The biggest problem for them is limited availability of texts in the appropriate format. Because of that they are forced to use existing recourses and read books in standard format (newspapers, instructions and labels on food and medications, sizes on clothes, street names, filling out standard forms) regardless of the degree of their disability (Bell et al., 2002; Dinsmore \& Kirchner, 2004, according to McMahon \& Curtis, 2009; Lamoureux et al., 2008; Latham \& Usherwood, 2010; Lindo \& Nordholm, 1999; Stelmack, Rosenbloom, Brenneman \& Stelmack, 2003; Tabrett \& Latham, 2012; Walter, Althouse, Humble, Smith \& Odom, 2007). This usually leads to giving up activities which are not indispensable at that moment, which then has a negative influence on functional literacy.

People who lose vision during life and who need training in learning Braille are at particular risk of becoming functionally illiterate. However, programs for learning Braille and computer training are rarely available to them in our country. Generally, in other countries people with a higher level of education are included in these programs (Crewe et al., 2011; Goudiras, Papadopoulos, Koutsoklenis, Papageorgiou \& Stergiou, 2009). Using visual aids in reading is of crucial importance for persons who gradually lose their vision. There is no difference in large and standard print reading speed in people who are trained to use magnifying devices (Corn, Wall \& Bell, 2000; Bell et al., 2002; Reid, 1998). Additionally, this reduces the cost of adapting reading materials and makes them available.

Children with visual impairment rarely express independence, self-advocacy and self-direction skills in their behavior (Agran, Hong \& Blankenship, 2007; Lieberman \& Robinson, 2004; Runjić, Bilić Prcić \& Alimović, 2015). Visual impairment, inadequate attitude of parents, teachers, and peers toward a blind or low vision child have a negative influence on the sense of security and self-assessment of the ability to make 
everyday decisions independently (Anđelković, Vučinić, Jablan \& Eškirović, 2015; Bardin \& Lewis, 2008; Lieberman \& Robinson, 2004). Many authors agree that young people with visual impairment are more dependent on others, they are submissive and have lower self-esteem compared to their typically developing peers (Petrucci, 1953; Warren, 1984, according to Head, 1992). Young people with visual impairment are not greatly interested in setting and achieving career goals (education and choice of profession) (Pfeiffer \& Pinquart, 2012). Numerous studies have determined that people who lose vision during their life are faced with lower self-confidence and self-respect, loss of personal security, and changes in interpersonal relations, i.e. self-withdrawal (Cherry, Keller \& Dudley, 1991; Van Hasselt, 1983, all according to Hersen et al., 1995; Senra, Vieira, Nicholls \& Leal, 2013). Nyman et al. believe that the above mentioned situation is not directly related only to visual impairment, but also to a person's inability to independently perform different activities in a new situation (Nyman, Dibb, Victor \& Gosneyet, 2012). Unknowns concerning a disease causing the impairment and concern for the future state of vision, are just some of the stressors which influence a person's psychosocial adaptation to acquired visual impairment (Kef, 2002).

With regard to the fact that conceptual skills have not been fully covered in previous studies, the subject of this research was this segment of adaptive skills and their relation to the time of onset, the category of visual impairment, and age.

\section{Research aims and tasks}

Aims of this research were the following:

1. To determine the acquisition level of conceptual skills in persons with visual impairment.

2. To determine the relation between conceptual skills and age, the category of visual impairment, and time of onset. 
Tasks of this research were:

1. To develop and apply a questionnaire for collecting data on independent variables (gender, age, the category of visual impairment, and time of onset of visual impairment).

2. To assess conceptual skills of persons with visual impairment.

\section{RESEARCH METHODOLOGY}

\section{Formation and description of the sample}

The sample included 127 participants with visual impairment, members of Belgrade Association of the Blind. Formation criteria were: visual impairment at the level of blindness and low vision, in accordance with the World Health Organization definition; 19-60 years of age, and average or above-average intellectual abilities. The sample consisted of 62 men (48.8\%) and 65 women (51.2\%). With regard to age, the participants were divided into four age groups (I from 19 to 24; II from 25 to 34; III from 35 to 45 ; and IV from 46 to 60 ). The first group included younger adults, who in the period between 19 and 24 years of age mainly study. The other two groups were equal in age, and in that period persons with visual impairment are usually employed. The fourth age group, from 46 to 60, included adults who at that period take early retirement. The first, second and fourth group each included 32 participants (25.2\%), and the third included 31 (24.4\%), (Mean=36.06; $\mathrm{SD}=11.777)$.

Most participants had a more severe form of visual impairment $(\mathrm{N}=79 ; 62.2 \%)$ and visual acuity under 0.05 , while 48 participants (37.8\%) were in the category of persons with low vision with visual acuity ranging from 0.05 to 0.3 . Congenital visual impairment was present in 79 participants (62.2\%), while acquired visual impairment was registered in 48 participants 
(37.8\%). By applying Chi-Square, it was determined that there were no significant differences between the prevalence of different visual impairment categories $\left(\chi^{2}=1.875, \mathrm{df}=3\right.$, $\mathrm{p}=0.599)$ and the time of onset $\left(\chi^{2}=7.458, \mathrm{df}=3 \mathrm{p}=0.059\right)$ with regard to age groups.

The research was conducted from November 2014 to July 2015. It was carried out personally with each participant. After obtaining responses from general information questionnaire, the instrument for assessing adaptive behavior was applied. All items were read to the participants, and their responses were recorded.

\section{Research instruments}

General demographic data (gender, age) and data referring to visual state (the category of visual impairment and time of onset) were collected by means of a specially designed questionnaire. Adaptive Behavior Assessment System II (ABAS, Harrison \& Oakland, 2003) was used to obtain data on conceptual skills of persons with visual impairment. The assessment system was designed as a complex scale for assessing adaptive skills, identifying strengths and weaknesses, and monitoring them over time. It was filled out by a person who knew the participant well, or the participant himself/ herself. Adaptive Behavior Assessment System consisted of three domains (Practical Skills, Social Skills, and Conceptual Skills) divided into ten subtests including the total of 239 items. Conceptual Skills Domain was divided into three subtests: communication, functional literacy, and self-direction, which included 77 items. For each item, a participant chose one of the four given answers (0) is not able, (1) - never or almost never when needed, (2) - sometimes when needed, and (3) - always or almost always when needed. The answers were added up within each subtest, and raw score was obtained. The value of standard score was determined with regard to three parameters: age, the person providing information (a participant himself/ 
herself, or a person who knew the participant well), and the values of raw score. Standard score value for the domains was obtained by adding up standard scores of subtests. Standard scores for all three domains were then converted to composite scores. The obtained total score for one of the domains made it possible to determine equivalent composite score value for standard score value, which depended on both age and the person who provided information. By converting raw scores to standard and composite scores, we could get an insight into the development level of participants' adaptive skills. Descriptive classification of scores on ABAS scale, more precisely classification of the adaptive behavior general score and the scores in domains and on subtests, could be used for gaining an insight into the development level of adaptive behavior. With regard to this classification, the obtained values of composite adaptive score and composite scores in domains were classified into one of the following levels: greatly superior (130 points or more), superior (120-129), above average (110119), average (90-109), below average (80-89), threshold (71-79), and extremely low (70 points or fewer). Standard score value on all subtests was determined with regard to the defined level it belonged to: superior (15 or more), above average (13$14)$, average (8-12), below average (6-7), borderline (4-5), and extremely low (3 or less). On the basis of this classification, acquisition level of adaptive skills could be determined for each score, i.e. the range obtained by comparing the achievements of one participant with the achievements of the normative group. The norm group, i.e. the sample with regard to which the scale was standardized, consisted of typically developing persons of the same age.

By calculating Cronbach's alpha coefficient, internal consistency of ABAS scale was tested. Standard scores were used in the analysis for each of the ten subtests. Reliability coefficient, $\alpha=0.77$, indicated a high homogeneity of the subtests within the scale. 


\section{Statistical data analysis}

Descriptive statistical measures were used in the analysis of the obtained data. Participants' achievements on the applied scale were presented by basic descriptive measures: arithmetic mean, standard deviation, minimum and maximum values.

Significance of differences in achievements on the applied scale, according to the defined independent variables, was assessed by analysis of variance (ANOVA) and Bonferroni post hoc test.

Homogeneity of the sample in independent variables was determined by Chi-Square. Pearson correlation coefficient was used to determine the correlation between independent variables. Scale reliability was assessed by internal consistency a coefficient.

\section{RESEARCH RESULTS AND DISCUSSION}

Table 1 shows basic descriptive measures of the results which the participants with visual impairment achieved on the subtests Communication, Functional Literacy, and Selfdirection, and in Conceptual Skills Domain in total.

Table 1 - Descriptive parameters of the results in Conceptual Skills Domain

\begin{tabular}{llcccc}
\hline Conceptual Skills & & Min & Max & M & SD \\
\hline \multirow{2}{*}{ Communication } & Raw score & 52 & 75 & 67.71 & 3.986 \\
\cline { 2 - 6 } & Standard score & 4 & 13 & 8.91 & 1.964 \\
\hline \multirow{2}{*}{ Functional Literacy } & Raw score & 29 & 77 & 52.72 & 9.908 \\
\cline { 2 - 6 } & Standard score & 1 & 10 & 3.37 & 2.189 \\
\hline \multirow{2}{*}{ Self-direction } & Raw score & 40 & 75 & 66.08 & 5.915 \\
\cline { 2 - 6 } & Standard score & 2 & 13 & 8.97 & 2.078 \\
\hline \multirow{2}{*}{ Conceptual Skills in total } & Standard score & 10 & 35 & 21.25 & 4.100 \\
\cline { 2 - 6 } & Composite score & 63 & 106 & 84.5 & 6.657 \\
\hline
\end{tabular}

Scores of participants with visual impairment on Conceptual Skills Domain subtests were in the range of extremely low or average. If we compare the composite score in Conceptual 
Skills Domain of participants with visual impairment with the norm sample, their achievements can be classified as below average $(\mathrm{M}=84.50)$. Below average achievement in this domain of adaptive behavior was the result of our participants' selfassessment on Functional Literacy subtest. Some items on this subtest possibly need to be modified, since in our country, documents and forms are not adapted to the needs of people with visual impairment.

Achievements of participants with visual impairment on Functional Literacy subtest (standard score value $\mathrm{M}=3.37$ ), compared to the norm sample, were in the extremely low category. This once again confirms that reading different kinds of texts, especially standard print, is a major difficulty for children and youth with visual impairment (Bell et al., 2002; Klinkosz, Sekowski \& Brambring, 2006; Papadopoulos et al., 2011). Even though money managing could be a problem for people with visual impairment due to difficulties in recognizing the value of paper notes, the concepts of time and money, as well as writing, were not a problem for them.

Communication skills were also not a major problem for the participants with visual impairment from our sample. Achievements on Communication subtest $(\mathrm{M}=8.91)$ were in the average range, which was significantly influenced by responses to claims related to the development of structural language aspect. This result is comparable with the results of several studies (James \& Stojanovik, 2007; Tadić et al., 2010). While collecting data, it was observed that most of our participants negatively valued their own skills related to non-verbal aspects of communication, primarily starting and ending a conversation. Other authors also give similar examples which point out deficits in pragmatic language aspect of people with visual impairment, such as difficulties in initiating and maintaining communication, stereotyped use of language, asking questions not related to the conversation context, lack of communication gestures (Frame, 2000; Perfect, 2001; Yildiz \& Duy, 2013). 
Mean values of our participants' standard scores were somewhat higher on Self-direction subtest $(\mathrm{M}=8.97)$, and were also in the average range with regard to the norm sample. Achievements on Self-direction subtest were characterized by major differences between the participants in self-assessing responsibilities and controlling emotions in different life situations. As concluded by a group of researchers from Greece (Papadopoulos et al., 2011), children with visual impairment have difficulties in independent and reasonable behavior, they find it difficult to predict an outcome before making a decision, they rarely apologize for their mistakes, and they cannot control anger. Most authors point out that the impairment and its consequences (Agran et al., 2007; Bardin \& Lewis, 2008), as well as inadequate attitude of parents and teachers toward children with visual impairment, have a negative influence on the sense of security and self-assessment of abilities to make independent decisions in everyday life (Anđelković, 2014; Eniola, 2007; Lieberman \& Robinson, 2004). Self-direction problems become more complex with age, thus these people even in adulthood often depend on the help of persons without visual impairment. Big differences in assessing self-direction skills between the participants could be related to individual differences in controlling emotions and predicting an outcome of their own behavior, as well as to being overprotected by parents.

A low negative correlation between the participants' age and conceptual skills $(\mathrm{r}=-0.318 ; \mathrm{p} \leq 0.000)$ was determined by Pearson correlation coefficient.

\section{Relation between independent variables and results in Conceptual Skills Domain}

By applying one-way analysis of variance, the influence of independent variables (age, the category of visual impairment, and time of onset) on the total score was determined in Conceptual Skills Domain. 
Specijalna edukacija i rehabilitacija (Beograd), Vol. 16, br. 1. 9-33, 2017.

Table 2 - Relation between age and score in Conceptual Skills Domain

\begin{tabular}{|c|c|c|c|c|c|c|c|c|}
\hline \multirow{2}{*}{\multicolumn{2}{|c|}{ Age group }} & \multicolumn{7}{|c|}{ Conceptual skills } \\
\hline & & M & SD & $F(3)$ & $\begin{array}{c}\text { df } \\
\text { between } \\
\text { groups }\end{array}$ & $\begin{array}{c}\text { df } \\
\text { within } \\
\text { groups }\end{array}$ & $p$ & $\eta^{2}$ \\
\hline From 19 to 24 & Standard score & 23.41 & 5.079 & & & & & \\
\hline From 25 to 34 & Standard score & 21.53 & 3.182 & 5801 & & & & \\
\hline From 35 to 45 & Standard score & 20.52 & 3.678 & 5.801 & 3 & 123 & 0.001 & 0.124 \\
\hline From 46 to 60 & Standard score & 19.53 & 3.292 & & & & & \\
\hline
\end{tabular}

There were significant differences in the acquisition of conceptual skills $(p=0.001)$ between the participants in different age groups (Table 2). The youngest participants (from 19 to 24 years of age) acquired conceptual skills the most, and there was a constant decrease in the achievements with age.

By comparing the achievements of visually impaired participants from four age groups, a statistically significant difference can be determined between the first (from 19 to 24 years of age) and third age group (from 35 to 45 years of age) $(\mathrm{p}=0.023)$; the first (from 19 to 24 years of age) and fourth age group (from 46 to 60 years of age) ( $\mathrm{p}=0.001)$ (Table 3$)$.

Table 3 - Relation between achievements in Conceptual Skills Domain and age groups

\begin{tabular}{|c|c|c|c|c|}
\hline & & $\begin{array}{c}25-34 \text { years } \\
\text { of age }\end{array}$ & $\begin{array}{c}35-45 \text { years } \\
\text { of age }\end{array}$ & $\begin{array}{c}46-60 \text { years } \\
\text { of age }\end{array}$ \\
\hline \multirow[t]{3}{*}{$19-24$ years of age } & $\begin{array}{l}\text { Mean } \\
\text { Difference }\end{array}$ & 1.88 & 2.89 & 3.88 \\
\hline & $\mathrm{p}$ & 0.335 & 0.023 & 0.001 \\
\hline & & $\begin{array}{c}19-24 \text { years } \\
\text { of age }\end{array}$ & $\begin{array}{c}\text { 35-45 years } \\
\text { of age }\end{array}$ & $\begin{array}{c}46-60 \text { years } \\
\text { of age }\end{array}$ \\
\hline \multirow[t]{3}{*}{$25-34$ years of age } & $\begin{array}{l}\text { Mean } \\
\text { Difference }\end{array}$ & -1.88 & 1.02 & 2.00 \\
\hline & $p$ & 0.335 & 1.000 & 0.249 \\
\hline & & $\begin{array}{c}19-24 \text { years } \\
\text { of age }\end{array}$ & $\begin{array}{c}\text { 25-34 years } \\
\text { of age }\end{array}$ & $\begin{array}{c}46-60 \text { years } \\
\text { of age }\end{array}$ \\
\hline \multirow[t]{3}{*}{$35-45$ years of age } & $\begin{array}{l}\text { Mean } \\
\text { Difference }\end{array}$ & -2.89 & -1.02 & 0.98 \\
\hline & $p$ & 0.023 & 1.000 & 1.000 \\
\hline & & $\begin{array}{c}19-24 \text { years } \\
\text { of age }\end{array}$ & $\begin{array}{c}\text { 25-34 years } \\
\text { of age }\end{array}$ & $\begin{array}{c}\text { 35-45 years } \\
\text { of age }\end{array}$ \\
\hline \multirow[t]{2}{*}{$46-60$ years of age } & $\begin{array}{l}\text { Mean } \\
\text { Difference }\end{array}$ & -3.88 & -2.00 & -0.98 \\
\hline & $p$ & 0.001 & 0.249 & 1.000 \\
\hline
\end{tabular}


The determined differences in favor of the youngest participants with visual impairment could be explained by the fact that they are still included in the school system, they have been trained to use a computer, low vision and other aids, which positively influences the acquisition of functional literacy skills (Adetoro, 2010; Bayir, Keser \& Numanoglu, 2010; Gerber \& Kirchner, 2001; Pfeiffer \& Pinquart, 2012). Older people with visual impairment, even with organized training, are often not motivated to learn how to use modern computer technology (Bayir et al., 2010), which has a negative influence on functional literacy in contemporary life conditions.

Participants from the youngest age group are probably socially more active compared to older persons with visual impairment, which can lead to their more frequent and better communication with people from the environment. Younger participants with visual impairment stated that they chose appropriate and current topics in conversation, carefully listened to interlocutors, and used non-verbal signals, all for the purpose of establishing good communication with people from the environment.

A more positive perception of self-direction skills in the youngest participants with visual impairment could be associated with the so-called period of prolonged childhood, in which neither persons with visual impairment nor people from their environment have high expectations related to achieving significant life goals, autonomy, emotional stability, and responsibility (Lieberman \& Robinson, 2004).

Table 4 - Relation between the categories of visual impairment and score in Conceptual Skills Domain

\begin{tabular}{|c|c|c|c|c|c|c|c|c|c|}
\hline \multirow{2}{*}{\multicolumn{2}{|c|}{$\begin{array}{l}\text { Category of } \\
\text { visual impairment }\end{array}$}} & \multicolumn{8}{|c|}{ Conceptual skills } \\
\hline & & \multirow{2}{*}{$\begin{array}{c}\text { Min } \\
10\end{array}$} & \multirow{2}{*}{$\begin{array}{r}\text { Max } \\
29\end{array}$} & \multirow{2}{*}{$\begin{array}{c}M \\
20.19\end{array}$} & \multirow{2}{*}{$\begin{array}{c}\text { SD } \\
3.645\end{array}$} & $\begin{array}{c}\text { df } \\
\text { between } \\
\text { groups } \\
\end{array}$ & $\begin{array}{l}\text { df } \\
\text { within } \\
\text { groups } \\
\end{array}$ & $F(1)$ & $p$ \\
\hline Blindness & $\begin{array}{l}\text { Standard } \\
\text { score }\end{array}$ & & & & & \multirow{2}{*}{1} & \multirow{2}{*}{125} & \multirow{2}{*}{15.659} & \multirow{2}{*}{0.000} \\
\hline Low vision & $\begin{array}{l}\text { Standard } \\
\text { score }\end{array}$ & 16 & 35 & 23.00 & 4.243 & & & & \\
\hline
\end{tabular}

Statistically significant values are marked in bold. 
Analysis of variance determined that low vision participants acquired conceptual skills significantly better than blind participants $(p \leq 0.000)$. It is possible that the way of perceiving personal functional literacy in the given circumstances influenced the observed difference. The obtained result is in accordance with previous studies which showed that people with more severe visual impairment had more pronounced difficulties in acquiring functional literacy skills (Bosman et al., 2006; de Verdier \& Ek, 2014; Gompel et al., 2002; Gompel et al., 2004; Mohammed \& Omar, 2011). Due to the fact that they can read standard print (with the help of optical low vision aids), people with low vision can perform some everyday tasks, while blind people usually cannot.

Regardless of their limitations in visual perception, people with low vision are more aware of the significance of non-verbal communication, which influences their selfassessment of communication skills acquisition. Acquiring communication skills can be limited in blind persons due to difficulties in the non-verbal aspect of communication, such as noticing signals related to starting and ending a conversation and using gestures in a certain context (Cole, 1998, према Galati et al., 2003; Jindal-Snape, 2005; Kim, 2003; Mallineni et al., 2006; Vučinić \& Eškirović, 2008).

Some authors believe that the sense of personal autonomy, self-respect, and responsibility are not affected by visual state, but are related to a personal perception of depending on others, education level, and employment status of a visually impaired person (Beach, Robinet \& Hakim-Larson, 1995; Cardinali \& D’Allura, 2001; Fok \& Fung, 2004; Huurre, Komulainen \& Aro, 1999; Pinquart \& Pfeiffer, 2011; Spencer, Head, Pysh \& Chalfant, 1997). However, Papadopoulos et al. determined that visual status was a significant predictor of self-esteem and locus of control of people with visual impairment (Papadopoulos et al., 2013).

It is possible that significantly better achievements of low vision participants in Conceptual Skills Domain were related to the acquisition level of self-direction skills, since blind persons 
are overprotected more often, which has a negative influence on personal autonomy, self-respect, and decision-making in everyday life (Anđelković et al., 2015; Bardin \& Lewis, 2008). Since the results of previous studies indicated that people with low vision had significantly more difficulties in selfdirection aspects than blind people (Papadopoulos et al., 2013; Stojković, Eminović, Dimoski, Grbović \& Nikić, 2011), the above mentioned assumption should be empirically tested in the future.

Table 5 - Relation between time of onset of visual impairment and score in Conceptual Skills Domain

\begin{tabular}{|c|c|c|c|c|c|c|c|c|c|}
\hline \multirow{2}{*}{$\begin{array}{l}\text { Time of onset } \\
\text { of visual } \\
\text { impairment }\end{array}$} & & \multicolumn{8}{|c|}{ Conceptual skills } \\
\hline & & Min & Max & M & SD & $\begin{array}{c}\text { df } \\
\text { Between } \\
\text { groups }\end{array}$ & $\begin{array}{c}\text { df } \\
\text { Within } \\
\text { groups }\end{array}$ & $F(1)$ & $\mathrm{p}$ \\
\hline Congenital & $\begin{array}{l}\text { Standard } \\
\text { score }\end{array}$ & 10 & 35 & 21.62 & 4.161 & & & & \\
\hline Acquired & $\begin{array}{l}\text { Standard } \\
\text { score }\end{array}$ & 10 & 28 & 20.65 & 3.965 & 1 & 125 & 1.696 & 0.195 \\
\hline
\end{tabular}

The achievements of participants with congenital visual impairment were expected to be significantly better, since persons with the acquired impairment, in a new situation, face difficulties in performing everyday activities which were previously not a problem for them, such as: reading newspapers and documents, labels on food and medications, street names, filling out different forms (Lamoureux et al., 2008; Latham \& Usherwood, 2010; Lindo \& Nordholm, 1999; Stelmack et al., 2003; Tabrett \& Latham, 2012; Walter et al., 2007). However, in our research, there were no statistically significant differences determined in the acquisition level of conceptual skills between participants with congenital and acquired visual impairment, which could be related to difficulties in functional literacy. Most people who lose vision during their life, do not learn to read and write in Braille, which is a rather neglected activity in our environment and wider.

Communication, as an integral part of conceptual skills, posed almost identical problems for participants with both acquired and congenital visual impairment. Tasks from 
Adaptive Behavior Assessment System include a wide range of communication skills. Thus, the obtained result could possibly be explained by difficulties in non-verbal aspect of communication. Gestures are acquired by imitation at an early age, and it is assumed that congenitally blind children cannot spontaneously learn to use gestures for the purpose of communication (Ekman \& Friesen, 1969; Wood, 1981, all according to Frame, 2000). In his research, Frame concluded that the time of vision loss influenced the extent to which a person could understand the meaning of gestures and use them adequately (Frame, 2000). Some of the responses led to a conclusion that regardless of the time of vision loss, the participants found it difficult to decide when they could start and/or end a conversation, since even though they knew communication gestures existed, they could not see them and recognize their meaning.

The inability of persons with acquired visual impairment to learn to perform different activities independently in a new situation is related to numerous factors. With regard to the life period when vision loss occurred, personal characteristics, requirements of the environment and their job, people with visual impairment experience difficulties in certain selfdirection aspects. On the other hand, unpredictability related to the impairment and future state of vision is one of more significant stressors which influence psychosocial adaptation of persons with acquired visual impairment (Kef, 2002). Fear of further loss of vision is very pronounced in persons with low vision and those who have lost vision in one eye (Janz et al., 2001, according to Nyman et al., 2012). People who have lost vision during their life are faced with the loss of self-confidence and selfrespect, changes in the sense of personal security, and changes in interpersonal relations (Cherry, Keller \& Dudley, 1991; Van Hasselt, 1983, all according to Hersen et al., 1995; Papadopoulos et al., 2013; Senra et al., 2013), while people with congenital visual impairment often do not have the opportunity to learn how to make decisions on their own and become independent. This probably influenced the fact that no difference in self-direction 
was determined between persons with acquired and congenital visual impairment. It is obvious that individual characteristics and personal strengths had the greatest influence on adapting to vision loss, gaining personal autonomy, self-confidence, selfrespect, and self-advocacy. It should be mentioned that there were more participants with congenital visual impairment than the ones with acquired visual impairment in the sample, which could additionally influence the fact that no statistically significant differences were determined between the two groups in Conceptual Skills Domain.

\section{CONCLUSION}

With regard to the aims of this research and the obtained results, we can conclude the following:

- The acquisition of conceptual skills in people with visual impairment was below average compared to the norm sample.

- In Conceptual Skills Domain, participants with visual impairment had the lowest achievements on Functional Literacy subtest, while they acquired communication skills somewhat better, and selfdirection skills the best.

- Age of participants with visual impairment significantly influenced the acquisition level of conceptual skills.

- Participants with low vision had fewer difficulties in acquiring conceptual skills than blind participants.

- Time when vision loss occurred was not a significant factor for acquiring conceptual skills.

With regard to the obtained results, it is possible to give recommendations for the acquisition of conceptual skills in persons with visual impairment:

- adequate reading materials should continuously be provided for people with visual impairment, since this 
has a direct influence on easier acquisition of functional literacy and everyday functioning in general;

- training for using computers and visual aids should be organized, and potential users informed;

- training for using assistive technology should be available from the earliest age;

- blind children should be trained to direct their attention to the interlocutor, identify and understand the consequences of inattentive listening, develop awareness of personal communication style, empathy, and skills needed for digital communication;

- training directed at the development of self-concept, decision-making, independent problem-solving, selfcontrol, and self-advocacy should be included in the existing programs.

\section{REFERENCES}

1. Adetoro, N. (2010). Reading interest and information needs of persons with visual impairment in Nigeria. South African Journal of Libraries \& Information Science, 76(1), 49-56.

2. Anđelković, M. (2014). Adaptivno ponašanje osoba sa oštećenjem vida. Specijalna edukacija i rehabilitacija, 13(4), 397-413. doi: 10.5937/specedreh13-7173

3. Анђелковић, М., Вучинић, В., Јаблан, Б. \& Ешкировић, Б. (2015). Образовање деце са оштећењем вида у редовној школи. У: Девета међународна научна конференција „Курикулумски исходи савременог васпитана и образована". Зборник радова. Суботица: Универзитет у Новом Саду - Учитељски факултет на мађарском наставном језику у Суботици. 26-34. 18-19. септембар.

4. Agran, M., Hong, S., \& Blankenship, K. (2007). Promoting the self-determination of students with visual impairments: Reducing the gap between knowledge and practice. Journal of Visual Impairment \& Blindness, 101(8), 453-464. 
5. Bardin, J. A., \& Lewis, S. (2008). A survey of the academic engagement of students with visual impairments in general education classes. Journal of Visual Impairment \& Blindness, 102(8), 472-483.

6. Bayir, Ş., Keser, H., \& Numanoğlu, G. (2010). General review on computer literacy of visually handicapped individuals in Turkey. Procedia-Social and Behavioral Sciences, 9, 1475-1480. doi.org/10.1016/j.sbspro.2010.12.352

7. Beach, J. D., Robinet, J. M., \& Hakim-Larson, J. (1995). Self-esteem and independent living skills of adults with visual impairments. Journal of Visual Impairment \& Blindness, 89(6), 531-540.

8. Bell, J., Corn, A., Jose, R., Perez, A., Wall, R., \& Wilcox, K. (2002). An initial study of reading and comprehension rates for students who received optical devices. Journal of Visual Impairment \& Blindness, 96(5), 322-334.

9. Bosman, A. M., Gompel, M., Vervloed, M. P., \& van Bon, W. H. (2006). Low vision affects the reading process quantitatively but not qualitatively. The Journal of Special Education, 39(4), 208-219.

10. Cardinali, G., \& D'Allura, T. (2001). Parenting styles and selfesteem: A study of young adults with visual impairments. Journal of Visual Impairment \& Blindness, 95(5), 261-271.

11. Corn, A., Wall, R., \& Bell, J. (2000). Impact of optical devices on reading rates and expectations for visual functioning of schoolage children and youth with low vision. Visual Impairment Research, 2(1), 33-41.

12. Crewe, J. M., Morlet, N., Morgan, W. H., Spilsbury, K., Mukhtar, A., Clark, A., ... \& Semmens, J. B. (2011). Quality of life of the most severely vision-impaired. Clinical \& experimental ophthalmology, 39(4), 336-343.

13. de Verdier, K., \& Ek, U. (2014). A longitudinal study of reading development, academic achievement, and support in Swedish inclusive education for students with blindness or severe visual impairment. Journal of Visual Impairment \& Blindness, 108(6), 461-472.

14. Dodd, B., \& Conn, L. (2000). The effect of braille orthography on blind children's phonological awareness. Journal of Research in Reading, 23(1), 1-11. 
15. Douglas, G., Hill, E., Long, R., \& Tobin, M. (2001). The generation of standardized print reading scores for children with low vision in Great Britain. British Journal of Visual Impairment, 19(1), 35-38.

16. Eniola, M. S. (2007). The influence of emotional intelligence and self-regulation strategies on remediation of aggressive behaviours in adolescent with visual impairment. Ethno-Medicine, 1(1), 71-77.

17. Fok, L. T., \& Fung, H. H. (2004). Self-Concept among people with and without visual impairment: The role of achievement motivation. Journal of Psychology in Chinese Societies, 5(1), 7-24.

18. Frame, M. (2000). The relationship between visual impairment and gestures. Journal of Visual Impairment \& Blindness, 94(3), 155-171.

19. Galati, D., Sini, B., Schmidt, S., \& Tinti, C. (2003). Spontaneous facial expressions in congenitally blind and sighted children aged 8-11. Journal of Visual Impairment and Blindness, 97(7), 418-428.

20. Gerber, E., \& Kirchner, C. (2001). Who's Surfing? Internet access and computer use by visually impaired youths and adults. Journal of Visual Impairment \& Blindness, 95(3), 176-181.

21. Gompel, M., J. van Bon, W., M. Adriaansen, J., \& Schreuder, R. (2002). Reading and spelling competence of Dutch children with low vision. Journal of Visual Impairment \& Blindness, 96(6), 435-447.

22. Gompel, M., J. van Bon, W., \& Schreuder, R. (2004). Reading by children with low vision. Journal of Visual Impairment \& Blindness 98(2), 77-89.

23. Goudiras, D. B., Papadopoulos, K. S., Koutsoklenis, A. C., Papageorgiou, V. E., \& Stergiou, M. S. (2009). Factors affecting the reading media used by visually impaired adults. British Journal of Visual Impairment, 27(2), 111-127.

24. Harrison, P., \& Oakland, T. (2003). Adaptive behavior assessment system (ABAS-II). San Antonio, Texax: The Psychological Corporation.

25. Head, D. (1992). Learned helplessness in children with visual handicaps:apilotstudy of expectations, persistence, and attributions. Final report. http://files.eric.ed.gov/fulltext/ED408791.pdf

26. Hersen, M., Kabacoff, R. I., Van Hasselt, V. B., Null, J. A., Ryan, C. F., Melton, M. A., \& Segal, D. L. (1995). Assertiveness, depression, 
and social support in older visually impaired adults. Journal of Visual Impairment \& Blindness, 89(6), 524-530.

27. Huurre, T. M., Komulainen, E. J., \& Aro, H. M. (1999). Social support and self-esteem among adolescents with visual impairments. Journal of Visual Impairment \& Blindness, 93(1), 26-37.

28. James, D. M., \& Stojanovik, V. (2007). Communication skills in blind children: A preliminary investigation. Child: care, health and development, 33(1), 4-10.

29. Jindal-Snape, D. (2005). Self-evaluation and recruitment of feedback for enhanced social interaction by a student with visual impairment. Journal of Visual Impairment \& Blindness, 99(8), 486-498.

30. Kef, S. (2002). Psychosocial adjustment and the meaning of social support for visually impaired adolescents. Journal of Visual Impairment \& Blindness, 96(1), 22-37.

31. Kim, Y.I. (2003). The effects of assertiveness training on enhancing the social skills of adolescents with visual impairments. Journal of Visual Impairment \& Blindness, 97(5), 285-297.

32. Klinkosz, W., Sekowski, A., \& Brambring, M. (2006). Academic achievement and personality in university students who are visually impaired. Journal of Visual Impairment \& Blindness, 100(11), 666-675.

33. Lamoureux, E. L., Pallant, J. F., Pesudovs, K., Tennant, A., Rees, G., O'Connor, P. M., \& Keeffe, J. E. (2008). Assessing participation in daily living and the effectiveness of rehabiliation in age related macular degeneration patients using the impact of vision impairment scale. Ophthalmic epidemiology, 15(2), 105-113.

34. Latham, K., \& Usherwood, C. (2010). Assessing visual activities of daily living in the visually impaired. Ophthalmic and Physiological Optics, 30(1), 55-65.

35. Lindo, G., \& Nordholm, L. (1999). Adaptation strategies, wellbeing, and activities of daily living among people with low vision. Journal of Visual Impairment \& Blindness, 93(7), 434-446. 
36. Mallineni, S., Nutheti, R., Thangadurai, S., \& Thangadurai, P. (2006). Non-verbal communication in children with visual impairment. British Journal of Visual Impairment, 24(1), 30-33.

37. McMahon, J. M., \& Curtis, A. (2009). Methods of reading information on labels of prescription medications by persons who are visually impaired. Journal of Visual Impairment \& Blindness, 103(5), 303-308.

38. Mohammed, Z., \& Omar, R. (2011). Comparison of reading performance between visually impaired and normally sighted students in Malaysia. British Journal of Visual Impairment, 29(3), 196-207.

39. Nyman, S. R., Dibb, B., Victor, C. R., \& Gosney, M. A. (2012). Emotional well-being and adjustment to vision loss in later life: a meta-synthesis of qualitative studies. Disability and rehabilitation, 34(12), 971-981.

40. Papadopoulos, K., Metsiou, K., \& Agaliotis, I. (2011). Adaptive behavior of children and adolescents with visual impairments. Research in developmental disabilities, 32(3), 1086-1096.

41. Papadopoulos, K., Montgomery, A. J., \& Chronopoulou, E. (2013). The impact of visual impairments in self-esteem and locus of control. Research in developmental disabilities, 34(12), 4565-4570.

42. Pfeiffer, J. P., \& Pinquart, M. (2012). Goal engagement and goal attainment in adolescents with and without visual impairment. Journal of adolescence, 35(4), 909-916.

43. Perfect, M. (2001). Examining communicative behaviors in a 3-year-old boy who is blind. Journal of Visual Impairment \& Blindness, 95(06), 353-365.

44. Pinquart, M., \& Pfeiffer, J. P. (2011). Psychological well-being in visually impaired and unimpaired individuals A meta-analysis. British Journal of Visual Impairment, 29(1), 27-45.

45. Reid, J. (1998). Assessing the literacy of adults who are visually impaired: conceptual and measurement issues. Journal of Visual Impairment \& Blindness, 92(7), 447-453.

46. Robinson, B., \& Lieberman, L. (2004). Effects of visual impairment, gender, and age on self-determination. Journal of Visual Impairment \& Blindness, 98(6), 351-366. 
47. Runjić, T., Bilić Prcić, A. \& Alimović, S. (2015). The relationship between social skills and behavioral problems in children with visual impairment. Hrvatska revija za rehabilitacijska istraživanja, 51(2), 64-75.

48. Senra, H., Vieira, C. R., Nicholls, E., \& Leal, I. (2013). Depression and experience of vision loss in group of adults in rehabilitation setting: Mixed-methods pilot study. Journal of rehabilitation research and development, 50(9), 1301-1313.

49. Spencer, R. A., Head, D. N., Pysh, M. V. D., \& Chalfant, J. C. (1997). Response patterns of children with visual impairments on measures of internalized self-responsibility. RE:view, 29(3), 121-127.

50. Stelmack, J. A., Rosenbloom, A. A., Brenneman, C. S., \& Stelmack, T. R. (2003). Patients' perceptions of the need for low vision devices. Journal of Visual Impairment \& Blindness, 97(9), 521-535.

51. Stojković, I., Eminović, F., Dimoski, S., Grbović, A., \& Nikić, R. (2011). Pojam o sebi slabovidih adolescenata i njihovih vršnjaka neoštećenog vida. Specijalna edukacija i rehabilitacija, 10(3), 467-478.

52. Tadić, V., Pring, L., \& Dale, N. (2010). Are language and social communication intact in children with congenital visual impairment at school age? Journal of Child Psychology and Psychiatry, 51(6), 696-705.

53. Tabrett, D. R., \& Latham, K. (2012). Important areas of the central binocular visual field for daily functioning in the visually impaired. Ophthalmic and Physiological Optics, 32(2), 156-163.

54. van Bon, W., Adriaansen, L., Gompel, M., \& Kouwenberg, I. (2000). The reading and spelling performance of visually impaired Dutch elementary schoolchildren. Visual Impairment Research, 2(1), 17-31.

55. Vučinić, V., \&Eškirović, B. (2008). Neverbalna komunikacija osoba sa oštećenjem vida. U D. Radovanović, (Ur.) U susret inkluziji dileme u teoriji i praksi, (str. 455-469). Beograd: Univerzitet u Beogradu - Fakultet za specijalnu edukaciju i rehabilitaciju.

56. Vučinić, V., Jablan, B., Stanimirović, D., \& Drinčić, N. (2015). Emocionalna ekspresivnost srednjoškolaca sa oštećenjem vida i njihovih vršnjaka tipičnog razvoja. Specijalna edukacija $i$ rehabilitacija, 14(4), 497-516. doi:10.5937/specedreh14-9115 
Specijalna edukacija i rehabilitacija (Beograd), Vol. 16, br. 1. 9-33, 2017.

57. Walter, C., Althouse, R., Humble, H., Smith, W., \& Odom, J. V. (2007). Vision rehabilitation: Recipients' perceived efficacy of rehabilitation. Ophthalmic epidemiology, 14(3), 103-111.

58. Yildiz, M. A., \& Duy, B. (2013). Improving empathy and communication skills of visually impaired early adolescents through a psychoeducation program. Educational Sciences: Theory \& Practice, 13(3), 1470-1476. 


\title{
KONCEPTUALNE VEŠTINE KOD OSOBA SA OŠTEĆENJEM VIDA
}

\author{
Marija Anđelković \\ Univerzitet u Beogradu - Fakultet za specijalnu edukaciju i rehabilitaciju
}

\begin{abstract}
Rezime
Konceptualne veštine omogućavaju razvoj sposobnosti neophodnih za rukovođenje nekim aspektima života. Obuhvataju komunikacione veštine, funkcionalnu pismenost i veštine samousmeravanja. Cilj ovog rada je utvrđivanje usvojenosti konceptualnih veština kod osoba sa oštećenjem vida. Istraživanje je sprovedeno na uzorku koji je činilo 127 osoba sa oštećenjem vida, starosti od 19 do 60 godina. Podaci o usvojenosti konceptualnih veština dobijeni su primenom Skale adaptivnog ponašanja (ABAS II), domen Konceptualne veštine. Utvrđeno je da starost $(\mathrm{p}=0,001)$, kategorija oštećenja vida (slepoća i slabovidost) $(\mathrm{p}=0,000)$, predstavljaju značajne činioce usvojenosti konceptualnih veština kod osoba sa oštećenjem vida. Sa druge strane, vreme nastanka oštećenja vida nije se izdvojilo kao značajan faktor za sticanje konceptualih veština kod osoba sa oštećenjem vida $(p=0,195)$.
\end{abstract}

Ključne reči: oštećenje vida, konceptualne veštine, komunikacione veštine, funkcionalna pismenost, veštine samosumeravanja 